\author{
Д.О. Корнеев, Л.В. Петракова, М.А. Понсов, А.А. Родионов \\ Федеральное государственное бюджетное учреждение \\ "27 Научный центр» Министерства обороны Российской Федерации, \\ 105005, г. Москва, Бригадирский переулок, 13
}

Поступила 29.01.2018 г. Принята к публикации 10.09.2018 г.

Актуальность разработки и совершенствования способов определения метаболитов (биомаркеров) отравляющих веществ (ОВ) в биологических жидкостях (крови, моче и т.д.) связана с необходимостью установления фактов воздействия ОВ на организм человека и животных. Необходимость в проведении таких анализов возникает в рамках наблюдения за выполнением положений Конвенции о запрещении химического оружия (КХО), при расследованиях предполагаемого применения ОВ, а также в ходе профессиональных тестов, проводимых Организацией по запрещению химического оружия (ОЗХО). В настоящее время имеется проблема определения низкомолекулярных биомаркеров иприта в биологических пробах методами газовой хроматографии с применением масс-селективного детектирования. Низкомолекулярными биомаркерами серного иприта являются тиодигликоль, оксиды и сульфоксиды иприта. Идентификация и количественная оценка содержания маркеров серного иприта в крови и моче осуществляется по методикам, основанным на вытеснении тиодигликоля и его производных из белковых конъюгатов с помощью трихлорида титана, твердофазной экстракции, концентрировании в растворе этилацетата, дериватизации пентафторбензоилхлоридом, гептафторбутирилимидазолом, ангидридом или хлорангидридом гептафтормасляной кислоты, последующей реэкстракции деривата в соответствующий растворитель и последующем газохроматографическом анализе в режиме химической ионизации метаном с регистрацией отрицательных ионов. После пробоподготовки проводилось определение пределов обнаружения минимальных значений сверхнизких концентраций анализируемых биомаркеров серного иприта в моче и плазме крови. Проведя хроматографический анализ, по результатам строили соответствующие графики зависимости показателей, исходя из концентрации исследуемых биомаркеров в моче и плазме крови, используемые в дальнейшем для разработки соответствующих методик по определению биомаркеров серного иприта в моче и крови человека.

\begin{abstract}
Ключевые слова: биомаркерь; $\beta$-лиазные метаболиты; Конвениия; нанопримеси; отравляющие вещества; подготовка пробы плазмы; пробоподготовка; токсичные химикать; химическое оружие; хроматографическое разделение; хроматографический пик; экологическое обследование.
\end{abstract}

Библиографическое описание: Корнеев Д.О., Петракова Л.В., Понсов М.А., Родионов А.А. Разработка методики определения низкомолекулярных биомаркеров заражения ипритом в пробах биологического происхождения // Вестник войск РХБ защитты. 2018. Т. 2. № 3. С. 40-54.

Необходимость и актуальность разработки и совершенствования различных методик определения метаболитов (биомаркеров) отравляющих веществ (ОВ) в биологических объектах связана с периодически возникающей необходимостью как экстренного, так и ретроспективного установления фактов воздействия ОВ на организм человека и животных. Последнее, в свою очередь, вытекает как из положений Конвенции о запрещении разработки, производства, накопления и применения химического оружия и о его уничтожении (КЗХО) [1] списки токсических веществ и их прекурсоров, для 
которых должны существовать надежные методики идентификации и обнаружения, содержатся в Приложениях 1-3 КЗХО, так и из сохраняющейся угрозы химического терроризма.

Низкомолекулярными метаболитами (биомаркерами) бис-2-хлорэтилового тиоэфира (серного иприта) являются тиодигликоль, его оксид и диоксид, сульфоксид и сульфон иприта. К $\beta$-лиазным метаболитам иприта относятся следующие соединения, представленные на схеме ниже: 1,1'-сульфонил-бис[2-S-(N-ацетилцистеинил)этан (SBSNAE), 1,1'-сульфонил-бис[2-(метилтио)этан] (SBMTE), 1-метилсульфинил-2-[2-(метилтио)этилсульфонил] этан (MSMTESE), 1,1'-сульфонилбис-[2-(метилсульфинил)этан] (SBMSE).<smiles>O=S(CCCl)CCCl</smiles><smiles>OCCSCCO</smiles>
TDG

\section{Материалы и методы}

Использованные реактивы и оборудование ${ }^{1,2}$ Реактивы

Азот газообразный нулевой марка А, НИИ КМ, ТУ 6-21-39-96, 99,999\%;

Ацетон, 99,5\%, Alfa Aesar, 32451;

Ацетонитрил, HPLC Grade, 99,7+ \%, Alfa Aesar, 22927;

Вода дистиллированная по ГОСТ 6709-72;

Гелий газообразный высокой чистоты, марка 7.0, НИИ КМ, ТУ 0271-001-4590571-02, 99,9999\%;

Гептан, для ВЭЖХ, 99+\%, Alfa Aesar, 22911;

Метан газообразный, НИИ КМ, ТУ 51-841-87, 99,9\%;

Метанол, HPLC Grade, 99,8+\%, Alfa Aesar, 22909;

Натрия гидроокись, хч, Химмед, ГОСТ 4328-75;

Пентафторбензоилхлорид, Sigma, 103772-25g;<smiles>O=S(=O)(CCO)CCO</smiles>

Hydrolysis, exidation

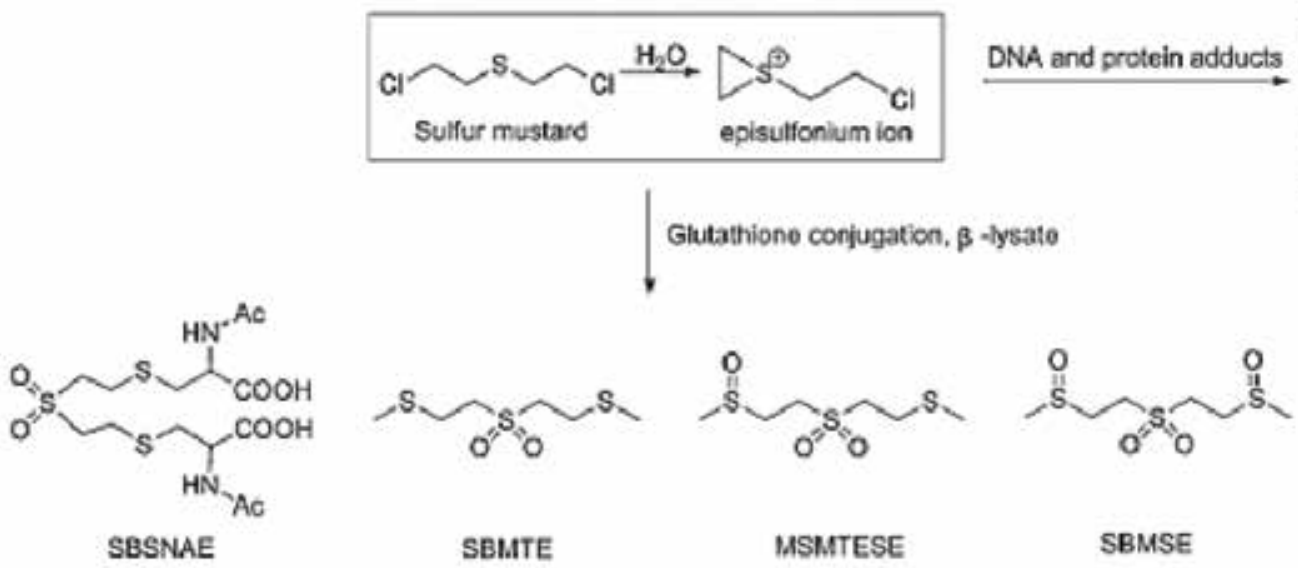

Для идентификации и количественной оценки содержания маркеров серного иприта в крови и моче эффективны методики, основанные на вытеснении тиодигликоля и его производных из белковых конъюгатов с помощью трихлорида титана, твердофазной экстракции, концентрировании в растворе этилацетата, дериватизации пентафторбензоилхлоридом, гептафторбутирилимидазолом, ангидридом или хлорангидридом гептафтормасляной кислоты, последующей реэкстракции деривата в соответствующий растворитель и ГХ-МС/MC анализе в режиме химической ионизации метаном с регистрацией отрицательных ионов.

Цель работы - разработка способа определения низкомолекулярных биомаркеров заражения ипритом в пробах биологического происхождения.
Пиридин, чда, Химмед, ГОСТ 13547-78;

Сульфат натрия, хч, Химмед, ГОСТ 4166-76;

Титан (Ш) хлорид, 10 \% в 20-30\% HCl, Aldrich, 24999-8;

Толуол, HPLC, Acros, 203-625-9;

Этилацетат, 99,7\%, Sigma-Aldrich, 34858.

\section{Оборудование}

ГХ-МС/МС система:

Газовый хроматограф «Agilent 7890A», трехквадрупольный масс-селективный детектор «Agilent 7000B GC/MS Triple Quad»;

Вакуумный коллектор Vacuum Manifold, Supelco, кат. № 57160-U;

Ванна ультразвуковая, Elma. S30H. Elmasonic, D-78224 Singen/Htw;

\footnotetext{
${ }^{1}$ Standard operating procedure for the organisation of OPCW biomedical proficiency tests (QDOC/LAB/SOP/ BioPT01. Issue 1, ReBision 1, dated 28 December 2016.

${ }^{2}$ Recommended Operating Procedures for Analysis in the Verification of Chemical Disarmament. 2017 ed. / Ed. Vanninen P. The Ministry for Foreign Affairs of Finland University of Helsinki. VERIFIN, Department of Chemistry P.O. Box 55, fi-00014 University of Helsinki, Finland. ISBN 978-952-10-7408-0 (pdf).
} 
Виалы 1,5 мл с конусом обжимные, Restek, 21051;

Виалы стеклянные с герметично завинчивающимися крышками вместимостью 8,0 мл фирмы Supelco, кат. № 27518;

Виалы стеклянные с герметично завинчивающимися крышками вместимостью 15,0 мл фирмы Supelco, кат. № 27161;

Вставки стеклянные вместимостью 0,2 мл фирмы Supelco, кат. № 24717;

Гайка для колонки универсальная, Agilent, кат. № 5181-8830;

Дозатор пипеточный переменного объема 0,5-10 мкл Sigma, Biohit, кат. № 725020;

Дозатор пипеточный переменного объема 20200 мкл, Sigma, Biohit, кат. № 725060;

Иглы тефлоновые Disposable Flow Control Valve Liners for the Visirprep, Supelco, кат. № 57059;

Калибровочный стандарт для МСД, Interlab, кат. № 8500-5995;

Картридж SILICA, 100 мг, Agilent Technologies, кат. № 5982-221;

Картридж SPE «OASIS HLB», Waters, 3 cc;

Колонка капиллярная DB-5MS, Interlab, кат. № 19091S-433;

Крышки для виал 1,5-2 мл обжимные, MN, кат. № 702730;

Лайнер Inert Liner, splitless, single taper, Agilent, кат. № 5181-3316I;

Лайнер стеклянный, Agilent, кат. № 5062-3587;

Лайнер стеклянный, Agilent, кат. № 5183-4647;

Набор для обслуживания ГX, Interlab, кат. № 5180-4162;

Набор принадлежностей для чистки детектора, Interlab, кат. № 9301-0985;
Наждачная бумага, Interlab, кат. № 5061-5896;

Наконечник к дозатору до 5 мл, Sigma, кат. № Z332925-2РAK;

Перчатки нейлоновые, Interlab, кат. № 8650-0030;

Проверочный стандарт, Interlab, кат. № 5188-5348;

Прокладка для лайнера O-ring, Agilent, кат. № 5188-5311

Салфетки для очистки МСД, Interlab, кат. № 9310-4828;

Тампоны для чистки МСД, Interlab, кат. № 5080-5400;

Термошкаф, HS 62A;

Тестовая смесь для GC/MS Semi-Vol Analyzer, Checkout Mix, Interlab, кат. № 5190-0473;

Ткань без волокон, Interlab, кат. № 05980-60051;

Ферулы металлические, Agilent, кат. № 5188-5361;

Шейкер, Tube Shaker TS-36.

\section{Результаты и обсуждение}

Оптимизация процедуры пробоподготовки

В качестве объектов исследования были выбраны наиболее характерные метаболиты серного иприта - тиодигликоль и SBMTE.

Наличие тиодигликоля в плазме крови и в моче определяли с помощью двух дериватизирующих реагентов: пентафторбензоилхлорида (PFBzCl) и гептафторбутирилимидазола (HFBI). $\quad \beta$-лиазный метаболит иприта SBMTE определяли в моче с помощью треххлористого титана - при взаимодействии последнего со смесью SBMSE и MSMTESE. В результате проведения процедуры дериватизации образуются аналиты 2,2'-тиобисэтанолдипентафторбензоат TDGPFB (1), бис(2-гептафторбутирилоксиэтил)сульфид TDGHFB (2) и SBMTE (3) по схеме:<smiles>CC(C)CC(C)C(=O)NCCSCCOC(=O)c1cccc(F)c1</smiles><smiles>CS(=O)CCS(C)(=O)=O</smiles>

SBMSE<smiles>CSCCS(C)(=O)=O</smiles>

MSMTESE<smiles>CSCCS(=O)(=O)CCl</smiles> 
Перед хромато-масс-спектрометрическим исследованием готовили соответствующие калибровочные растворы стандартов изучаемых аналитов (1-3).

\section{Подготовка стандартного раствора TDGPFB (1)}

Для приготовления растворов тиодигликоля (ТДГ) в этилацетате с концентрациями $1 \times 10^{-3} ; 1 \times 10^{-4} ; 1 \times 10^{-5} ; 1 \times 10^{-6}$ и $1 \times 10^{-7}$ мг/мл проводили дериватизацию каждого раствора: к 500 мкл раствора добавляли 200 мг сульфата натрия, перемешивали на вортексе 10 мин и центрифугировали; к отобранной аликвоте добавляли 15 мкл пиридина, 20 мкл пентафторбензоилхлорида и 10 мкл метанола (выпадает белый осадок); смесь перемешивали на вортексе 10 мин и центрифугировали; к отобранной аликвоте добавляли 200 мг сульфата натрия, перемешивали на вортексе 10 мин и опять центрифугировали.

Si-SPE-картридж (100 мг) кондиционировали 1 мл этилацетата, 200 мкл реакционной смеси пропускали через картридж и затем пропускали 400 мкл чистого этилацетата. Фракции $(200+400$ мкл) объединяли и проводили ГХ-МС/MC анализ ${ }^{3}$ [2].

Подготовка пробы мочи для определения ТДГ с использованием $\mathrm{PFBzCl}$

Картридж «OASIS HLB» кондиционировали 1 мл ацетонитрила и 1 мл воды. 1 мл урины наносили на картридж, промывали 0,5 мл воды и сушили 5 мин под слабым вакуумом («манифолд»). Смывали в чистую виалу 2,0 мл аналиты ацетонитрила (2 раза по 0,75 мл). Упаривали смесь в токе азота досуха при $400^{\circ} \mathrm{C}$. Добавляли 50 мкл пиридина и 10 мкл $\mathrm{PFBzCl}$, смесь перемешивали на вортексе и выдерживали 5 мин при комнатной температуре. Добавляли 440 мкл толуола, перемешивали на вортексе, центрифугировали при 3000 об/мин в течение 10 мин. Отделяли в чистую виалу надосадочную жидкость и проводили ГХ-МС/МС анализ ${ }^{4}[3]$.

Осаждение белков из плазмь крови и разложение аддуктов

В виале 12,0 мл к 1 мл плазмы крови добавляли 10 мл ацетона и помещали в шейкер на 10 мин. Охлаждали до 50 C и центрифугировали при $4300 \mathrm{~g} 10$ мин. Сливали ацетон, к осадку приливали 6-7 мл чистого ацетона и повторяли промывку с перемешиванием, охлаждением и центрифугированием. Сливали ацетон и промывали чистым ацетоном с перемешиванием, охлаждением и центрифугированием еще раз.
Виалу с осадком накрывали марлей (бинтом) и закрепляли ее, чтобы при сушке не «вылетел» легкий осадок, после чего помещали виалу в вакуумный эксикатор и высушивали осадок при комнатной температуре (примерно 1 ч).

После высушивания 25 мг осадка переносили в виалу 4,0 мл, добавляли 200 мкл 1 М раствора $\mathrm{NaOH}$ и нагревали в термошкафу при $700{ }^{\circ} \mathrm{C}$ до полного растворения (примерно 2 ч). Добавляли 70 мкл $3 \mathrm{M} \mathrm{HCl}, 1$ мл этилацетата и перемешивали на шейкере 10 мин. Добавляли 200 мг сульфата натрия, перемешивали на шейкере 10 мин и центрифугировали при 3000 об/мин в течение 10 мин. Отбирали аликвоту 500 мкл в виалу 2,0 мл.

Далее проводили дериватизацию: в виалу 2,0 мл к 500 мкл раствора добавляли 200 мг сульфата натрия, перемешивали на шейкере 10 мин и центрифугировали при 3000 об/мин в течение 10 мин.; к отобранной в виалу 2,0 мл аликвоте добавляли 15 мкл пиридина, 20 мкл PFBzCI (выпадает белый осадок) и 10 мкл метанола; смесь перемешивали на шейкере 10 мин и центрифугировали при 3000 об/мин в течение 10 мин; к отобранной в виалу 2,0 мл аликвоте добавляли 200 мг сульфата натрия, перемешивали на шейкере 10 мин и центрифугировали при 3000 об/ мин в течение 10 мин.

Si-SPE картридж (100 мг) кондиционировали 1 мл этилацетата, 200 мкл реакционной смеси пропускали через картридж и затем пропускали 400 мкл чистого этилацетата. Фракции $(200+400$ мкл) объединяли и проводили ГХ-МС/MС анализ ${ }^{5}$ [4].

Приготовление растворов метаболита TDGHFB (2) для определения в моче

Картридж «OASIS HLB» кондиционировали 1 мл ацетонитрила и 1 мл воды, 1 мл урины наносили на картридж, промывали 0,5 мл воды и сушили 5 мин под слабым вакуумом. Смывали в чистую виалу (1,5 мл) аналиты ацетонитрилом (2 раза по 0,75 мл). Упаривали смесь в токе азота досуха при $40{ }^{\circ} \mathrm{C}$, перерастворяли осадок в 200 мкл ацетонитрила. Добавляли 30 мкл гептафторбутирилимидазола и выдерживали в термошкафу 30 мин при $50{ }^{\circ} \mathrm{C}$. Смесь охлаждали, добавляли 200 мкл воды, перемешивали на шейкере. Экстрагировали гептаном (2 раза по 300 мкл) и выдерживали в ультразвуковой ванне по 5 мин. Отобранные фракции объединяли в виале 2,0 мл и упаривали в токе азота до 200 мкл, смесь переносили в виалу со вставкой и концентрировали в токе азота до 50 мкл. Фракции объединяли и проводили ГХ-МС/MС анализ ${ }^{6}$ [4].

\footnotetext{
3 Standard operating procedure...

4 Ibid.

5 Ibid.

6 Ibid.
} 
Подготовка пробы плазмы для определения ТДГ с использованием НFВI

В виалу 10,0-12,0 мл к 1 мл плазмы добавляли 10 мл ацетона и помещали в шейкер на 10 мин. Охлаждали до $5^{\circ} \mathrm{C}$ и центрифугировали при 4300 g 10 мин. Сливали ацетон, к осадку приливали 6-7 мл чистого ацетона и повторяли промывку с перемешиванием, охлаждением и центрифугированием. Сливали ацетон и промывали чистым ацетоном с перемешиванием, охлаждением и центрифугированием еще раз.

Виалу с осадком накрывали марлей (бинт) и закрепляли ее, чтобы при сушке не «вылетел» легкий осадок, после чего помещали виалу в вакуумный эксикатор и высушивали осадок при комнатной температуре (примерно 1 ч).

После высушивания 25 мг осадка переносили в виалу 4,0 мл, добавляли 200 мкл 1 М раствора $\mathrm{NaOH}$ и нагревали в термошкафу при $70{ }^{\circ} \mathrm{C}$ до полного растворения (примерно 2 ч). Добавляли 70 мкл $3 \mathrm{M} \mathrm{HCl}, 1$ мл этилацетата и перемешивали на шейкере 10 мин. Добавляли 200 мг сульфата натрия, перемешивали на шейкере 10 мин и центрифугировали при 3000 об/мин в течение 10 мин. Отбирали аликвоту 500 мкл в виалу 2,0 мл.

Далее проводили дериватизацию: в виалу 2,0 мл к 500 мкл раствора добавляли 200 мг сульфата натрия, перемешивали на шейкере 10 мин и центрифугировали при 3000 об/мин в течение 10 мин; надосадочную жидкость отбирали в чистую виалу, упаривали в токе азота при $40^{\circ} \mathrm{C}$ досуха и перерастворяли в 200 мкл ацетонитрила; добавляли к смеси 30 мкл гептафторбутирилимидазола и выдерживали в термошкафу 30 мин при $50{ }^{\circ} \mathrm{C}$, смесь охлаждали, добавляли 200 мкл воды, перемешивали на шейкере, экстрагировали гептаном (2 раза по 300 мкл) и выдерживали в ультразвуковой ванне по 5 мин, центрифугировали при 3000 об/мин в течение 10 мин; отобранные фракции объединяли в виале 2,0 мл и упаривали в токе азота до 200 мкл, смесь переносили во вставку и концентрировали в токе азота до 50 мкл. Фракции объединяли и проводили ГХ-МС/МС анализ 7 [5].

Подготовка пробы мочи для определения $\beta$-лиазных метаболитов с трихлоридом титана $\left(\mathrm{TiCl}_{3}\right)$ - определение биомаркера SBMTE (3)

Готовили «стандартную» пробу урины следующим образом: по 5 мкл стандартов Std SBMSE и Std MSMTESE с C $=10$ мкг/мл вносили в виалу 4,0 мл, добавляли 0,99 мл урины, в случае бланка - 1,0 мл урины. К пробе урины (1 мл) прибавляли 1 мл 15\% раствора $\mathrm{TiCl}_{3}$ в $30 \% \mathrm{HCl}$, смесь выдерживали 1 ч при $75^{\circ} \mathrm{C}$. После охлаждения осторожно (вспенивание) добавляли к смеси 1 мл $10 \mathrm{M} \mathrm{NaOH}$. Выпавший осадок отде- ляли центрифугированием при 4000 об/мин в течение 10 мин. Надосадочную жидкость отделяли, переносили в виалу 4,0 мл и центрифугировали повторно (при необходимости еще раз). Картридж «OASIS HLB» кондиционировали 2 мл метанола и затем 4 мл воды. Супертанант, не содержащий взвеси, наносили на картридж, промывали 2 мл воды, сушили 15 мин под вакуумом и смывали аналиты 3 мл метанола (виала 4,0 мл).

Смесь переносили в чистую виалу 4,0 мл и упаривали досуха, перерастворяли в 200 мкл смеси (180 мкл толуола + 20 мкл ацетонитрила). Элюат упаривали досуха при $50{ }^{\circ} \mathrm{C}$, осадок перерастворяли в 3 мл ацетонитрила, если появлялся осадок или взвесь, то центрифугировали при 4000 об/мин в течение 10 мин. Смесь перемешивали на шейкере и выдерживали в ультразвуковой ванне 5 мин. Смесь переносили в виалу со вставкой и концентрировали до 50 мкл, в случае бланка - до 100 мкл, и проводили ГХ-МС/МС анализ [5].

Синтез соответствующих стандартов (1-3) TDGPFB (1), TDGHFB (2) и SBMTE (3) проводили по известным методикам. Содержание полученных целевых продуктов (по данным хромато-масс-спектрометрии) составляло 97-99,5\%.

Пробоподготовка стандартов для последующего хроматографического разделения и масс-детектирования заключалась в обычном приготовлении растворов данных веществ в соответствующих растворителях с концентрациями от 0,01 до 500 нг/мл.

Выєор условий хроматографического разделения и масс-детектирования низкомолекулярных биомаркеров серного иприта

Оптимизированные условия хроматографического разделения и масс-спектрометрического детектирования определяемых биомаркеров (1-3) представлены в таблице 1.

Определение оптимальных значений энергии ячейки соударений для исследуемых биомаркеров

При использовании трехквадрупольных масс-селективных детекторов максимальная интенсивность (Int) хроматографического сигнала в режиме сканирования MRM зависит в основном от оптимальной энергии ячейки соударений (CE) для основного масс-энергетического перехода. Эта величина является индивидуальной для каждого исследуемого органического соединения, и в условиях проводимого эксперимента всегда рассчитывается при варьировании энергии в пределах 1-35 эВ с помощью программного обеспечения. 
Elaboration of a method for the determination of low-molecular-weight mustard gas biomarkers...

Таблица 1 - Оптимальные параметры газохроматографического разделения и масс-спектрометрического детектирования для определения сверхнизких концентраций маркеров серного иприта в биоорганических пробах (моча и кровь) для хроматографа «Agilent 7890A» и трехквадрупольного масс-селективного детектора «Agilent 7000B GC/MS Triple Quad» в режимах биполярной метановой химической ионизации

\begin{tabular}{|c|c|c|c|}
\hline \multirow{2}{*}{$\begin{array}{c}\text { Параметр хроматографического } \\
\text { разделения и масс- } \\
\text { спектрометрического детектирования }\end{array}$} & \multicolumn{3}{|c|}{ Значение параметра для определяемых аналитов 1-3 } \\
\hline & TDGPFB (1) & TDGHFB (2) & SBMTE (3) \\
\hline Ввод пробы & \multicolumn{3}{|c|}{ Программируемый, с помощью автосамплера «Agilent 7693А» } \\
\hline Объем вводимого раствора аналита, мкл & \multicolumn{3}{|c|}{1,0} \\
\hline Режим ввода пробы & \multicolumn{3}{|c|}{ Без разделения потока (Splitless) } \\
\hline Температура ввода пробы (испаритель), ${ }^{\circ} \mathrm{C}$ & 250 & 200 & 250 \\
\hline Время задержки растворителя, мин & 4,0 & 3,5 & 3,5 \\
\hline Тип ввода пробы & \multicolumn{3}{|c|}{ Вертикальный } \\
\hline $\begin{array}{c}\text { Тип и неподвижная фаза хроматографической } \\
\text { колонки }\end{array}$ & \multicolumn{3}{|c|}{$\begin{array}{l}\text { Agilent DB-5MS Ultra Inert / (5\% фенил 95\% диметилариленсилоксан), } \\
\text { ЗО м × } 0.25 \text { мм × 0.25 мк }\end{array}$} \\
\hline $\begin{array}{c}\text { Режим программирования температуры } \\
\text { термостата колонки }\end{array}$ & $\begin{array}{l}80^{\circ} \mathrm{C}(1 \text { мин }) \\
30^{\circ} \mathrm{C} / \text { мин } 225^{\circ} \mathrm{C}(11 \text { мин }) \\
50^{\circ} \mathrm{C} / \text { мин } 300^{\circ} \mathrm{C}(2 \text { мин })\end{array}$ & $\begin{array}{c}80^{\circ} \mathrm{C}(1 \text { мин }) \\
20^{\circ} \mathrm{C} / \text { мин } 280^{\circ} \mathrm{C}(4 \text { мин })\end{array}$ & $\begin{array}{l}90^{\circ} \mathrm{C}(2 \text { мин }) \\
20^{\circ} \mathrm{C} / \text { мин } \\
290^{\circ} \mathrm{C}(4 \text { мин })\end{array}$ \\
\hline Газ-носитель & \multicolumn{3}{|c|}{$\begin{array}{l}\text { Гелий сжатый газообразный высокой чистоты марки «7.0», } \\
\text { чистота не менее 99,99999\% (по ТУ 0271-001-45905715-02) }\end{array}$} \\
\hline $\begin{array}{c}\text { Скорость потока гелия через колонку, } \\
1 \text { мл/мин }\end{array}$ & \multicolumn{3}{|c|}{ Постоянная } \\
\hline $\begin{array}{c}\text { Скорость и время потока гелия после } \\
\text { разгонки }\end{array}$ & $\begin{array}{l}60 \text { мл/мин в течение } \\
2 \text { мин }\end{array}$ & $\begin{array}{c}60 \text { мл/мин в течение } \\
3 \text { мин }\end{array}$ & $\begin{array}{c}50 \text { мл/мин в течение } \\
2 \text { мин }\end{array}$ \\
\hline Вакуум внешнего насоса, мм рт. ст. & \multicolumn{3}{|c|}{$(2,18-2,23) \cdot 10^{-1}$} \\
\hline Вакуум внутреннего турбонасоса, мм рт. ст. & \multicolumn{3}{|c|}{$(7,78-7,79) \cdot 10^{-5}$} \\
\hline Скорость потока гелия через септу, мл/мин & \multicolumn{3}{|c|}{3,0} \\
\hline $\begin{array}{l}\text { Число промываний иглы шприца } \\
\text { абсолютным хлористым метиленом } \\
\text { (до ввода пробы и после) }\end{array}$ & \multicolumn{3}{|c|}{6} \\
\hline Тип масс-селективного детектора & \multicolumn{3}{|c|}{$\begin{array}{c}\text { фирмы «Agilent» - проприетарный кварцевый гексапольный анализатор с } \\
\text { гиперболической поверхностью электродов и многослойным композитно- } \\
\text { золотым покрытием }\end{array}$} \\
\hline Режим масс-селективного детектирования & \multicolumn{3}{|c|}{ «SRM» (мониторинг множественных реакций) } \\
\hline $\begin{array}{l}\text { Определяемые основные масс- } \\
\text { энергетические переходы, }\end{array}$ & $\mathrm{m} / \mathrm{z} 510 \rightarrow 211,167$ & $\mathrm{~m} / \mathrm{z} 301 \rightarrow 241,169$ & $\mathrm{~m} / \mathrm{z} 215,167 \rightarrow 75$ \\
\hline $\begin{array}{l}\text { Энергия ячейки соударений для масс- } \\
\text { энергетических переходов }\end{array}$ & $\begin{array}{l}4 \text { эB }(\mathrm{m} / \mathrm{z} 510 \rightarrow 211) \\
10 \ni B(\mathrm{~m} / \mathrm{z} 510 \rightarrow 167)\end{array}$ & $\begin{array}{l}6 \text { эB }(\mathrm{m} / \mathrm{z} 301 \rightarrow 241) \\
14 \text { эB }(\mathrm{m} / \mathrm{z} 301 \rightarrow 169)\end{array}$ & $\begin{array}{l}10 \text { эB }(\mathrm{m} / \mathrm{z} 215 \rightarrow 75) \\
15 \text { эB }(\mathrm{m} / \mathrm{z} 167 \rightarrow 75)\end{array}$ \\
\hline Полярность химической ионизации & Отрицательная & Положительная & Положительная \\
\hline $\begin{array}{l}\text { Внутренний калибровочный стандарт для } \\
\text { химической ионизации }\end{array}$ & \multicolumn{3}{|c|}{ Перфтор-5,8-диметил-3,6,9-триоксидодекан (ПФДТД) } \\
\hline Газ-реагент для химической ионизации & \multicolumn{3}{|c|}{$\begin{array}{c}\text { Метан газообразный марки «4.0», чистота не менее } 99,99 \% \\
\text { (по ТУ 51-841-87) }\end{array}$} \\
\hline Газ ячейки соударений & \multicolumn{3}{|c|}{$\begin{array}{c}\text { Азот сжатый газообразный высокой чистоты, чистота не менее 99,9999\% } \\
\text { (по ТУ 2114-009-45905715-2011) }\end{array}$} \\
\hline $\begin{array}{l}\text { Скорость потока метана в ячейке } \\
\text { соударений, мл/мин }\end{array}$ & 2,0 мл/мин & 1,0 мл/мин & 1,0 мл/мин \\
\hline $\begin{array}{c}\text { Скорость потока гелия в ячейке соударений, } \\
\text { мл/мин }\end{array}$ & \multicolumn{3}{|c|}{2,25} \\
\hline \begin{tabular}{|c|} 
Время удерживания максимальной высоты \\
сигнала (пика) хроматограммы, мин
\end{tabular} & 12,46 & 5,44 & 9,60 \\
\hline $\begin{array}{c}\text { Скорость потока азота в ячейке соударений, } \\
\text { мл/мин }\end{array}$ & \multicolumn{3}{|c|}{1,5} \\
\hline Температура источника ионов, ${ }^{\circ} \mathrm{C}$ & 150 & 190 & 250 \\
\hline Температура переднего квадруполя, ${ }^{\circ} \mathrm{C}$ & 200 & 150 & 150 \\
\hline Температура заднего квадруполя, ${ }^{\circ} \mathrm{C}$ & 200 & 150 & 150 \\
\hline
\end{tabular}




\begin{tabular}{|c|c|c|c|}
\hline \multirow{2}{*}{$\begin{array}{c}\text { Параметр хроматографического } \\
\text { разделения и масс- } \\
\text { спектрометрического детектирования }\end{array}$} & \multicolumn{3}{|c|}{ Значение параметра для определяемых аналитов 1-3 } \\
\hline & TDGPFB (1) & TDGHFB (2) & SBMTE (3) \\
\hline Диапазон сканируемых масс, m/z & $42-550$ & $42-750$ & $35-500$ \\
\hline Время сканирования, циклов/с & 5,2-9,8 (35-51 мс/цикл) & 5,2-9,8 (35-51 мс/цикл) & $\begin{array}{c}5,2-9,8 \\
\text { (35-51 мс/цикл) }\end{array}$ \\
\hline Масс-разрешение & Unit & Unit & Unit \\
\hline Ширина щели пучка ионов, условных ед. & 100 & 150 & 150 \\
\hline Шаг сканирования, а.е.м. & \multicolumn{3}{|c|}{0,1} \\
\hline Порог детектирования, условных ед & \multicolumn{3}{|c|}{100} \\
\hline Коэффициент усиления сигнала (Gain) & \multicolumn{3}{|c|}{10} \\
\hline Энергия эмиссии электронов, эВ & 200 & 225 & 225 \\
\hline Сила тока эмиссии электронов, мкА & 150 & 135 & 180 \\
\hline Ширина детектируемого пика, с & \multicolumn{3}{|c|}{0,7} \\
\hline
\end{tabular}

Математическая зависимость при этом фактически должна быть всегда дифференцированная (степенная), а вторая координата точки экстремума получаемой функции (шкалы ординат) должна являться оптимальным показателем энергии ячейки соударений.

Расчеты зависимости интенсивности сигнала (Int) от показателя энергии ячейки coyдарений (CE) проводили для значений концентрации проб $\mathrm{C}=100,0$ нг/мл (100 ppb) для биомаркеров (1-3) с использованием лицензионного программного обеспечения для математической и статистической обработки данных ${ }^{8,9}$.

Полученные экспериментальные зависимости интенсивности сигнала (Int) от показателя энергии ячейки соударений (CE) для биомаркеров (1-3) для основных масс-энергетических переходов представлены на рисунках 1-3.

Проведенная математическая (статистическая) обработка данных с использованием ПЭВМ и стандартизированного программного обеспечения позволила оценить полученные результаты, получить следующую зависимость и вывести уравнение:

Int $(\mathrm{m} / \mathrm{z}(510 \rightarrow 167))=-38,194(\mathrm{CE})^{2}+$ $+786,41(\mathrm{CE})+1684,3$,

где:

Int - интенсивность сигнала основного масс-энергетического перехода $\mathrm{m} / \mathrm{z}(510 \rightarrow 167)$, отн. ед.; $\mathrm{CE}$ - энергия ячейки соударений, эВ.

\footnotetext{
${ }_{8}^{8}$ Руководство пользователя работы с газовым хроматографом «Agilent 7890A» и масс-селективным детектором «Agilent 7000B GC/MS Triple Quad». Программное обеспечение для управления и обработки данных "Mass Hunter Workstation Software, Qualitative and Quantitative Analysis, version B.04.00 build 4.0.479.0», фирма «Agilent Technologies», США, 2013.

${ }^{9}$ Программное обеспечение для математических расчетов «Mathcad», Add-In for Excel, ver. 15.0.8 for Windows 7,8,XP, Microsoft\&Co, 2015.
}

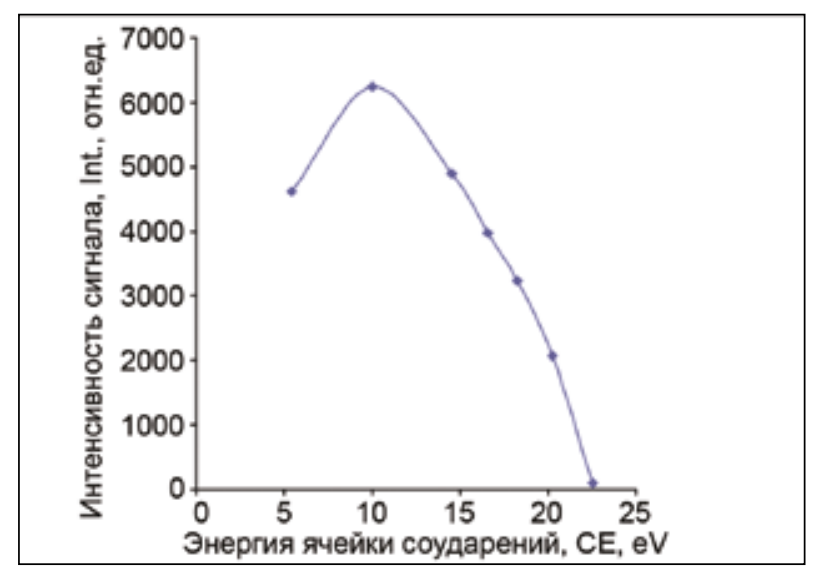

Рисунок 1 - Зависимость интенсивности сигнала (Int) хроматографического пика от показателя энергии ячейки соударений (CE) для биомаркера TDGPFB (1) для основного масс-энергетического перехода $m / z 510 \rightarrow 167$ (концентрация пробы 100,0 нг/мл)

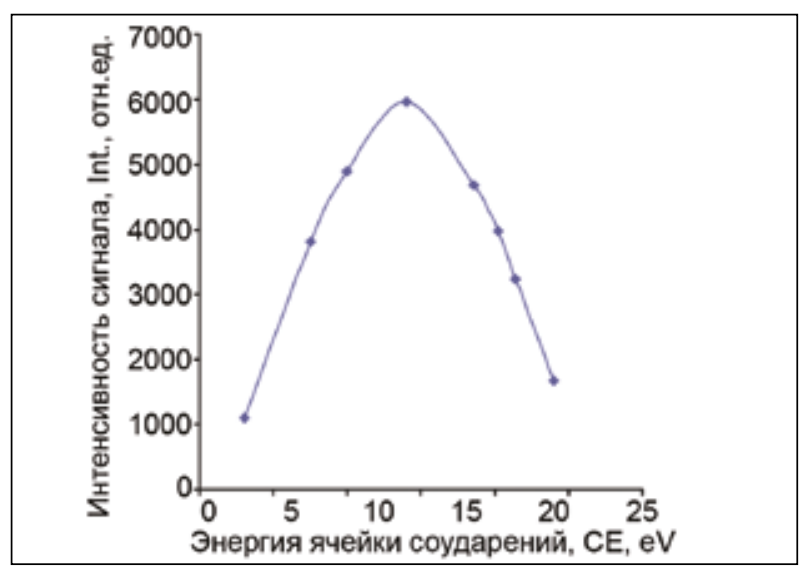

Рисунок 2 - Зависимость интенсивности сигнала (Int) хроматографического пика от показателя энергии ячейки соударений (CE) для биомаркера TDGHFB (2) для основного масс-энергетического перехода m/z $301 \rightarrow 169$ (концентрация пробы 100,0 нг/мл) 
Математическая обработка данных и линии тренда данного графика позволила определить следующие основные статистические показатели полученной зависимости:

$\mathrm{R}^{2}=0,9893 ; \mathrm{R}=0,98 ; \beta=-0,947 ; \mathrm{F}=529,9 ; \mathrm{df}=1,93 ;$ $\mathrm{P}=0 ; \mathrm{B}=12,89$; Std.error $=0,127$.

Полученные показатели зависимости свидетельствуют о валидности полученной математической модели. Точка экстремума полученной функции соответствует максимальному значению интенсивности сигнала при наиболее оптимальной энергии ячейки соударений $(\mathrm{CE}=$ 10,0 эВ), что соответствует экспериментальным данным.

Наложенная линия тренда на экспериментальную кривую кореллирует с полученной зависимостью с вероятностью более 0,98 .

Аналогичное исследование было проведено с биомаркером (2), рисунок 2.

Как и в предыдущих двух случаях, проведенная математическая (статистическая) обработка данных с использованием ПЭВМ и стандартизированного программного обеспечения позволила оценить полученные результаты, получить следующую зависимость и вывести уравнение:

Int $(\mathrm{m} / \mathrm{z}(167 \rightarrow 75))=-24,09(\mathrm{CE})^{2}+$ $+715,1(\mathrm{CE})-1196,3$,

где:

Int - интенсивность сигнала основного массэнергетического перехода $\mathrm{m} / \mathrm{z}(167 \rightarrow 75)$, отн. ед.;

$\mathrm{CE}$ - энергия ячейки соударений, эВ.

Дальнейшая математическая обработка данных и линии тренда данного графика позволила определить следующие основные статистические показатели полученной зависимости:

$\mathrm{R}^{2}=0,9828 ; \mathrm{R}=0,962 ; \beta=-0,96 ; \mathrm{F}=563 ; \mathrm{df}=1,82 ;$ $\mathrm{P}=0 ; \mathrm{B}=12,00$; Std.error $=0,14$.

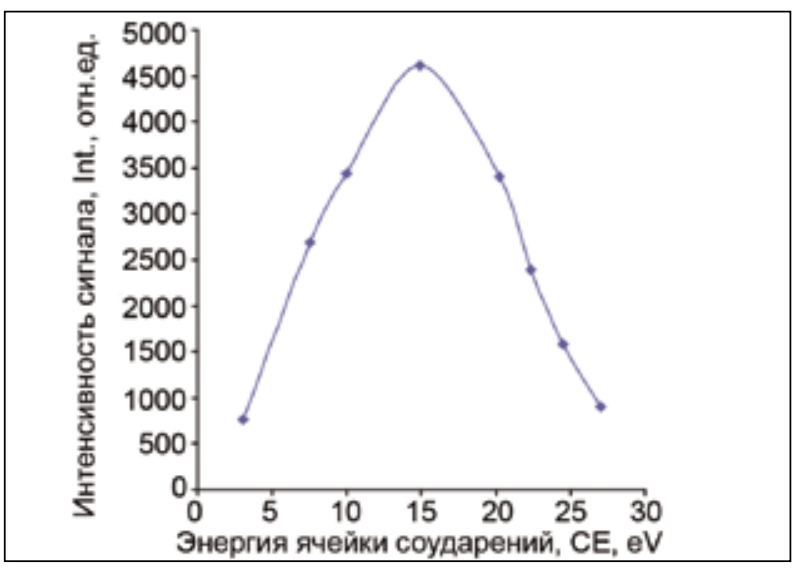

Рисунок 3-Зависимость интенсивности сигнала (Int) хроматографического пика от показателя энергии ячейки соударений (CE) для биомаркера SBMTE (3) для основного масс-энергетического перехода $\mathrm{m} / \mathrm{z} 167 \rightarrow 75$ (концентрачия пробы 100,0 нг/мл)

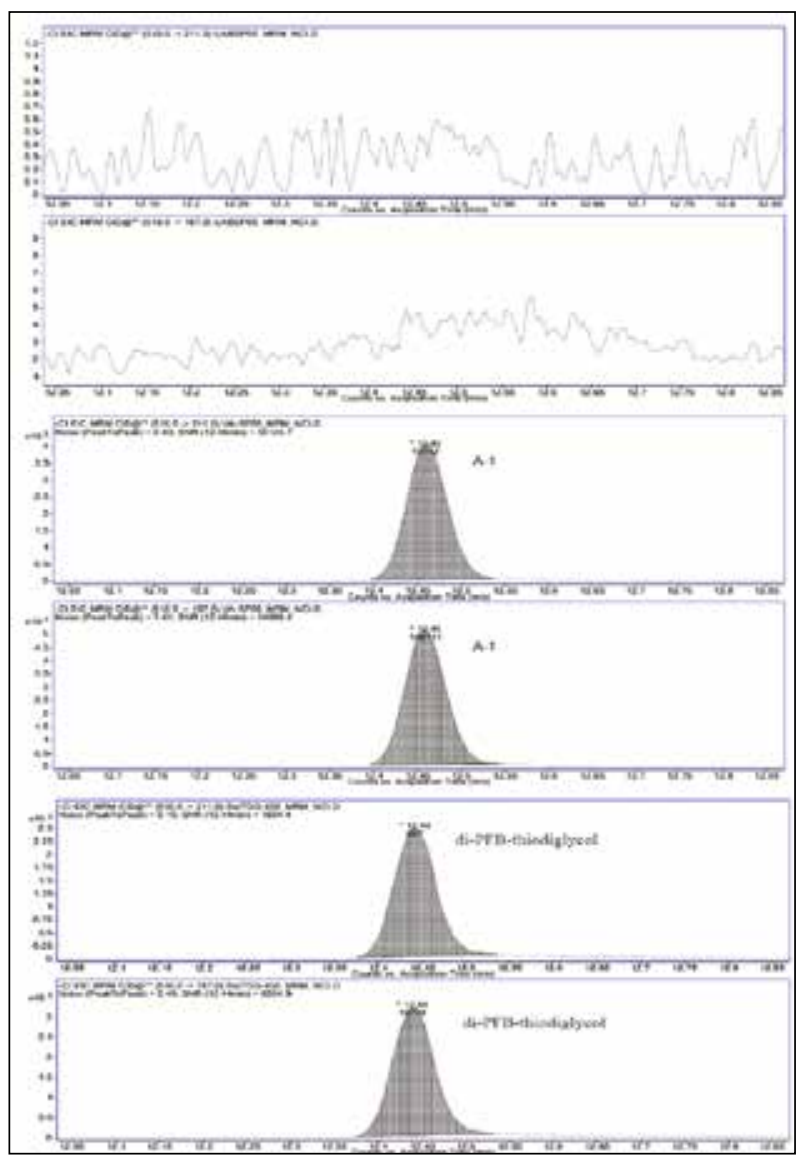

Рисунок 4-MRM-хроматограммы бланка, пробы определяемого биомаркера TDGPFB (1) и стандарта исследуемого аналита по основным массэнергетическим переходам $\mathrm{m} / \mathrm{z} 510 \rightarrow 211,167$

Полученные показатели зависимости свидетельствуют о валидности полученной математической модели. Точка экстремума полученной функции соответствует максимальному значению интенсивности сигнала при наиболее оптимальной энергии ячейки соударений $(\mathrm{CE}=$ 15,0 еВ), что соответствует экспериментальным данным.

Наложенная линия тренда на экспериментальную кривую коррелирует с полученной зависимостью с вероятностью более 0,98 .

Таким образом, в данном подразделе исследований были определены оптимальные значения энергии ячейки соударений для исследуемых биомаркеров (1-3).

Результаты хроматографического разделения и масс-спектрометрического детектирования биомаркеров

Хроматографическое разделение и масс-спектрометрическое детектирование в режиме МС/MС-сканирования для биомаркеров (1-3) проводили в соответствии с настройками прибора, указанными в таблице 1 . В целях достоверности результатов перед каждым введением 


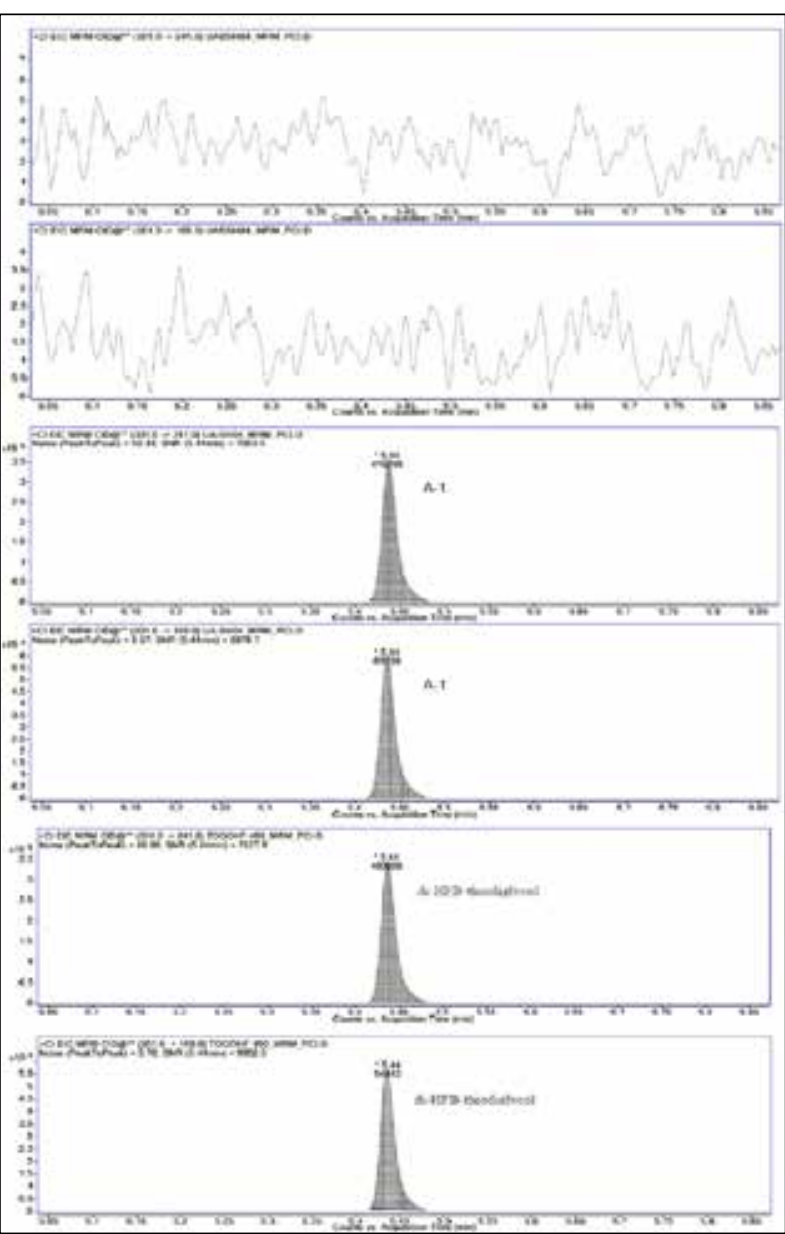

Рисунок 5-MRM-хроматограммы бланка, пробы определяемого биомаркера TDGHFB (2) и стандарта исследуемого аналита по основным массэнергетическим переходам $\mathrm{m} / \mathrm{z} 301 \rightarrow 241,169$

(вколом) растворов определяемых биомаркеров (1-3) вводили холостую (бланковую) пробу соответствующего растворителя. На каждом последующем шаге в целях сравнительного анализа проводили анализ стандартов исследуемых проб, которые были синтезированы по известным методикам ${ }^{10,11}$.

На рисунках 4-6 представлены MRM-хроматограммы бланков, определяемых биомаркеров (1-3) и соответствующих им стандартов по двум основным масс-энергетическим переходам.

Определение пределов обнаружения биомаркеров в моче и в плазме крови

После проведенной пробоподготовки очередным этапом исследования явилось определение пределов обнаружения минимальных значений сверхнизких концентраций анали-

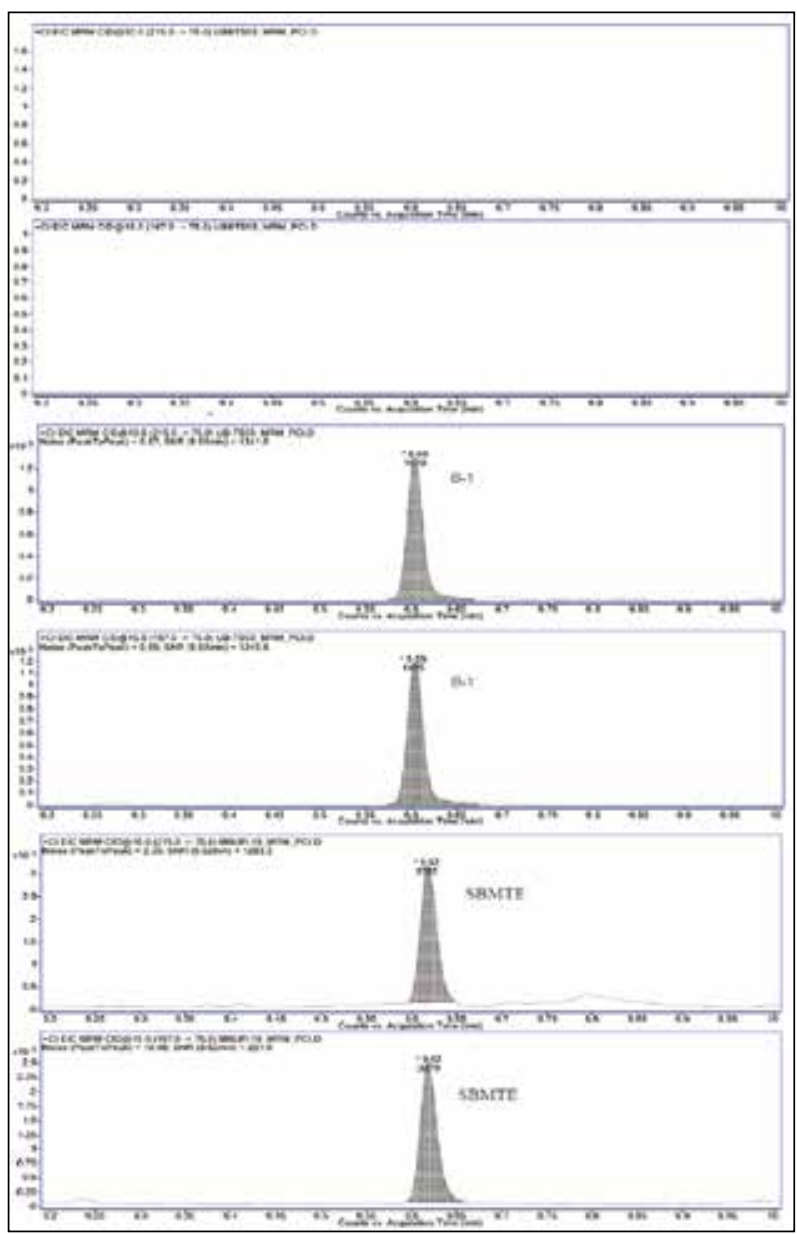

Рисунок 6-MRM-хроматограммы бланка, пробы определяемого биомаркера SBMTE (3) и стандарта исследуемого аналита по основным массэнергетическим переходам $\mathrm{m} / \mathrm{z} 215,167 \rightarrow 75$

зируемых биомаркеров серного иприта (1-3) в моче и плазме крови.

В экспериментах использовались только сертифицированные ОЗХО моча и плазма крови.

В качестве минимального принималось значение интенсивности хроматографического сигнала и шума (SNR), равное 5. При меньшем значении данного показателя идентификация вещества не является достоверной в связи с сопоставимостью величин интенсивностей нанопримесей (шум) и самого определяемого вещества. Соотношение сигнал/шум (SNR) и площади хроматографических пиков биомаркеров серного иприта (1-3) рассчитывались с помощью соответствующего программного

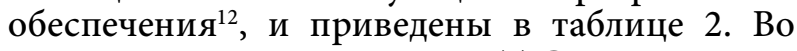
всех случаях оценивались TIC-MRM-хроматограммы, включающие в себя два основных масс-энергетических перехода.

\footnotetext{
${ }^{10}$ Руководство пользователя...

${ }^{11}$ Программное обеспечение...

${ }^{12}$ Там же.
} 
Elaboration of a method for the determination of low-molecular-weight mustard gas biomarkers...

Таблица 2 - Отношение показателей сигнал/шум (SNR) от концентрации исследуемых биомаркеров серного иприта (1-3) в различных биосредах

\begin{tabular}{|c|c|c|c|}
\hline Биомаркер/биосреда & $\begin{array}{c}\text { Концентрация } \\
\text { метаболита, С, нг/мл }\end{array}$ & $\begin{array}{c}\text { Площадь } \\
\text { хроматографического пика, } \\
\text { TIC-MRM (суммарно по } \\
\text { двум масс-энергетическим } \\
\text { переходам), S, усл. ед. }\end{array}$ & $\begin{array}{c}\text { Отношение } \\
\text { сигнал/шум, SNR, } \\
\text { усл. ед. }\end{array}$ \\
\hline \multirow{8}{*}{ TDGPFB (1) / моча } & 0,05 & 5 & 3,5 \\
\hline & 0,1 & 11 & 10,3 \\
\hline & 0,25 & 20 & 94 \\
\hline & 0,5 & 46 & 119 \\
\hline & 1,0 & 78 & 128 \\
\hline & 2,0 & 140 & 156 \\
\hline & 5,0 & 280 & 218 \\
\hline & 10,0 & 409 & 276 \\
\hline \multirow{9}{*}{ TDGHFB (2) / моча } & 0,1 & 187 & 5,2 \\
\hline & 0,25 & 359 & 22,7 \\
\hline & 0,5 & 745 & 98,3 \\
\hline & 1,0 & 1486 & 177 \\
\hline & 10,0 & 3597 & 344 \\
\hline & 50,0 & 9366 & 2007 \\
\hline & 100 & 28101 & 30765 \\
\hline & 300 & 85289 & 47014 \\
\hline & 450 & 169543 & 66117 \\
\hline \multirow{7}{*}{ TDGHFB(2) / плазма крови } & 0,25 & 17,1 & 6,0 \\
\hline & 0,5 & 38 & 77 \\
\hline & 5,0 & 205 & 251 \\
\hline & 10,0 & 416 & 402 \\
\hline & 20,0 & 944 & 1276 \\
\hline & 50,0 & 2154 & 31542 \\
\hline & 100,0 & 3965 & 37802 \\
\hline \multirow{6}{*}{ SBMTE (3) / моча } & 0,5 & 28 & 5,5 \\
\hline & 1,0 & 454 & 13 \\
\hline & 5,0 & 2324 & 39 \\
\hline & 10,0 & 7151 & 136 \\
\hline & 50 & 17802 & 259 \\
\hline & 100 & 33147 & 389 \\
\hline \multirow{6}{*}{ TDGPFB (1) / плазма крови } & 0,25 & 18,1 & 6,3 \\
\hline & 0,5 & 48 & 69 \\
\hline & 5,0 & 213 & 278 \\
\hline & 10 & 454 & 441 \\
\hline & 20 & 898 & 1273 \\
\hline & 50 & 1892 & 5432 \\
\hline
\end{tabular}

Проведя анализ полученных выше ре- используя программное обеспечение для мазультатов, представленных в таблице 2 , и тематической обработки данных ${ }^{13}$, строили

\footnotetext{
${ }_{13}^{13}$ Программное обеспечение...
} 


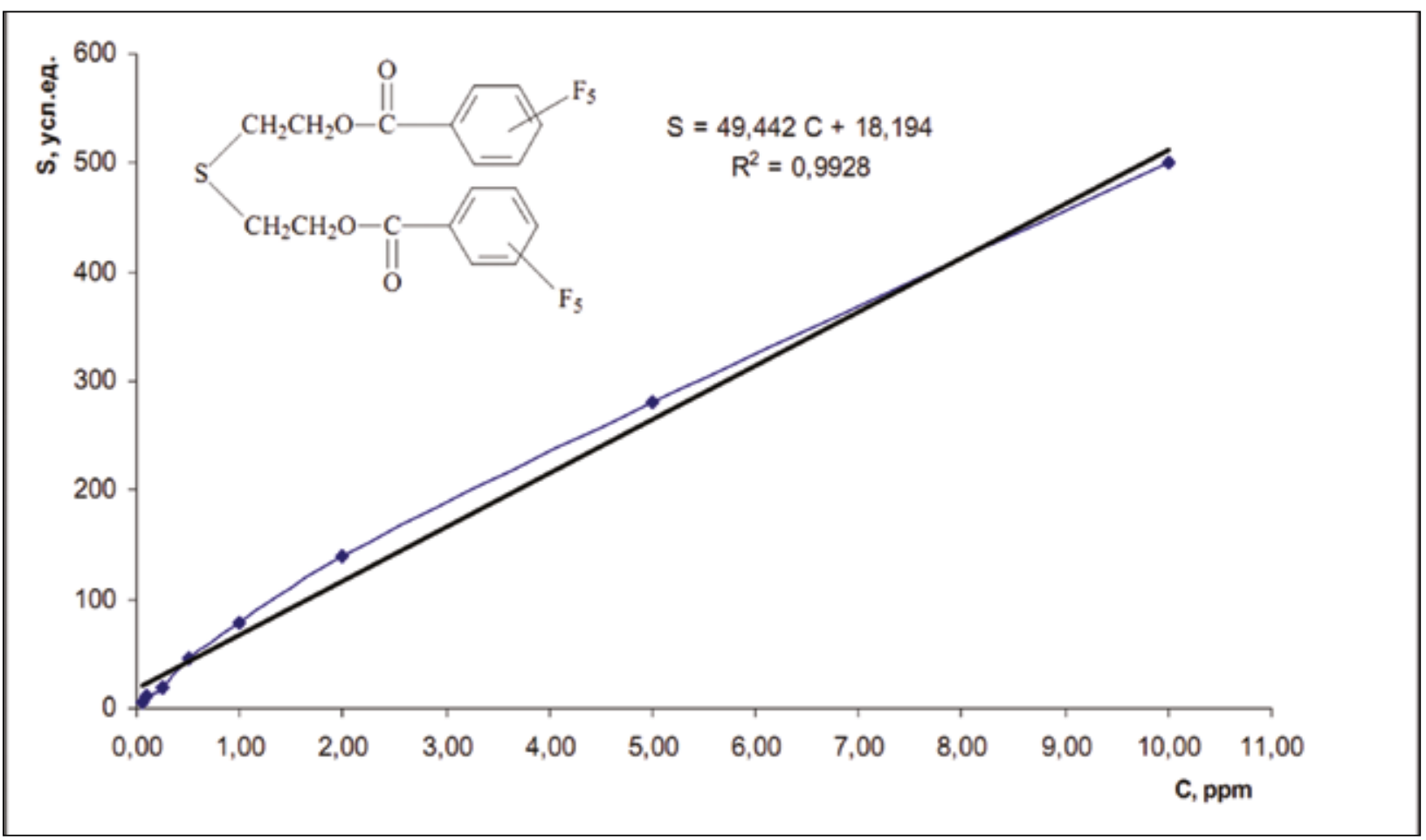

Рисунок 7 - График зависимости показателя площади хроматографического пика TIC-MRM (по двум массэнергетическим переходам) от концентрации TDGPFB (1) в моче (сналоженной линией тренда)

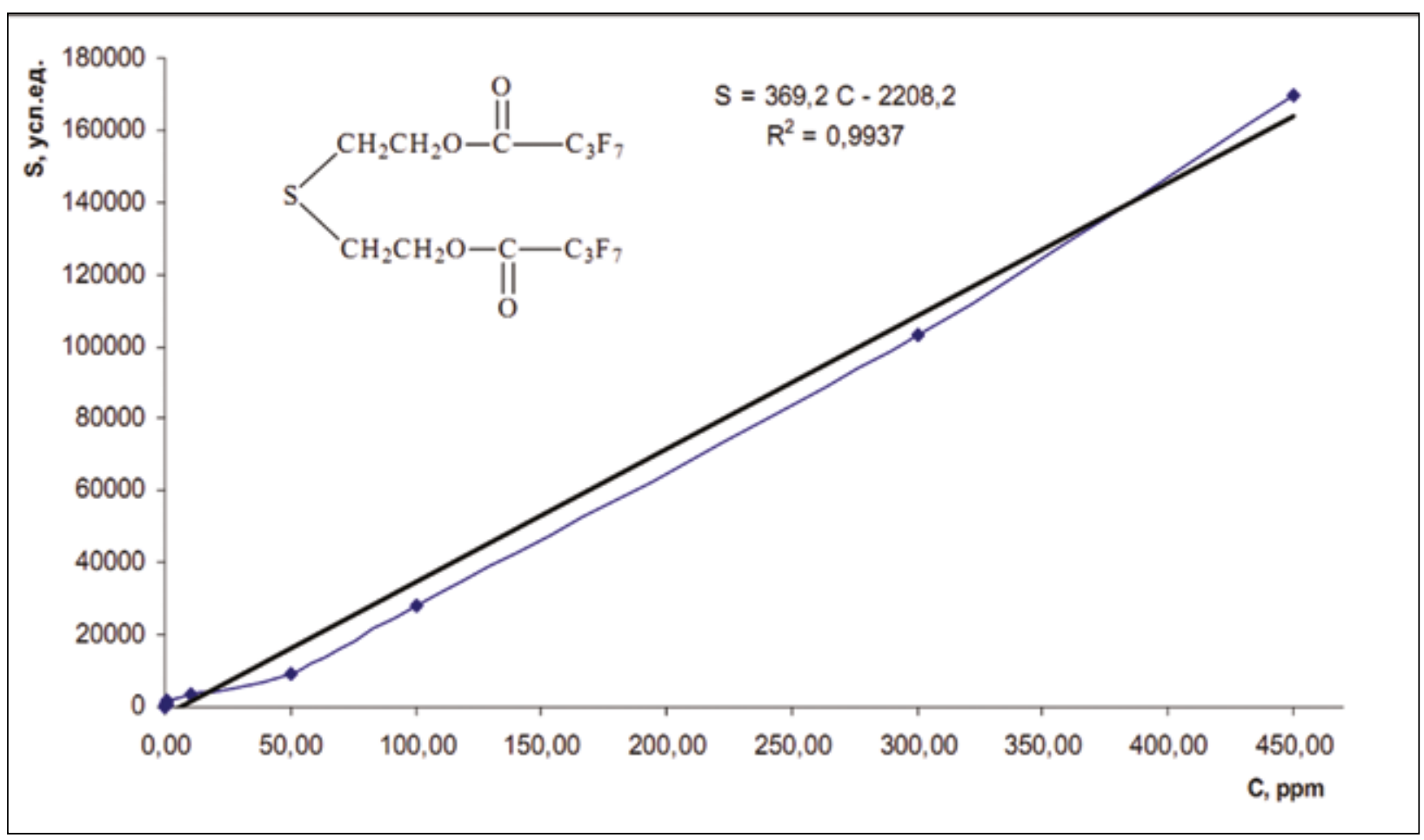

Рисунок 8 - График зависимости показателя площади хроматографического пика TIC-MRM (по двум массэнергетическим переходам) от концентрации TDGHFB (2) в моче (сналоженной линией тренда)

соответствующие графики зависимости показателей площади хроматографического пика TIC-MRM (по двум масс-энергетическим переходам) от концентрации исследу- емых биомаркеров (1-3) в моче и в плазме крови (рисунки 7-11).

Как видно из приведенных выше зависимостей показателей площади хроматогра- 


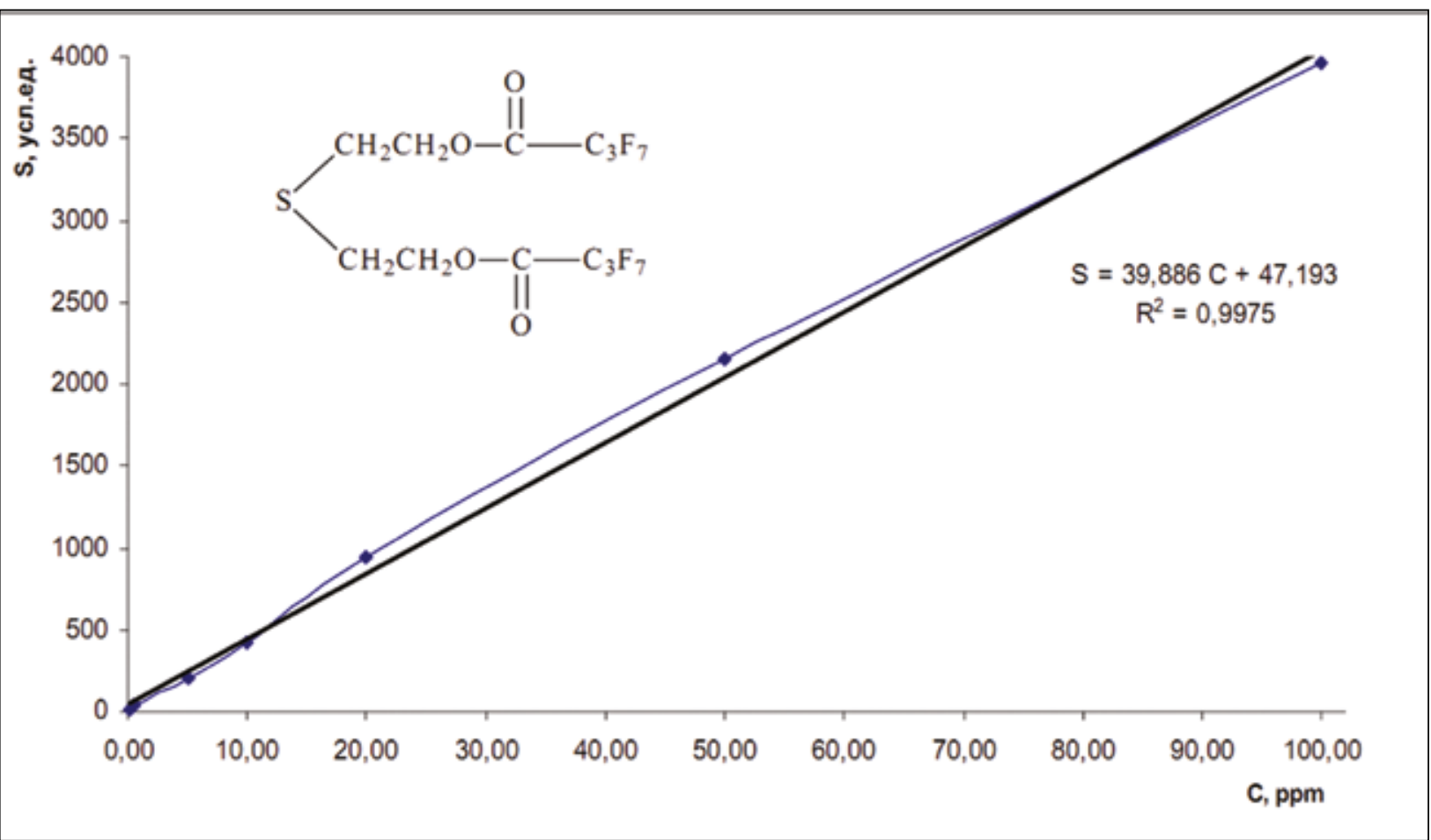

Рисунок 9- График зависимости показателя площади хроматографического пика TIC-MRM (по двум массэнергетическим переходам) от концентрации TDGHFB (2) в плазме крови (сналоженной линией тренда)

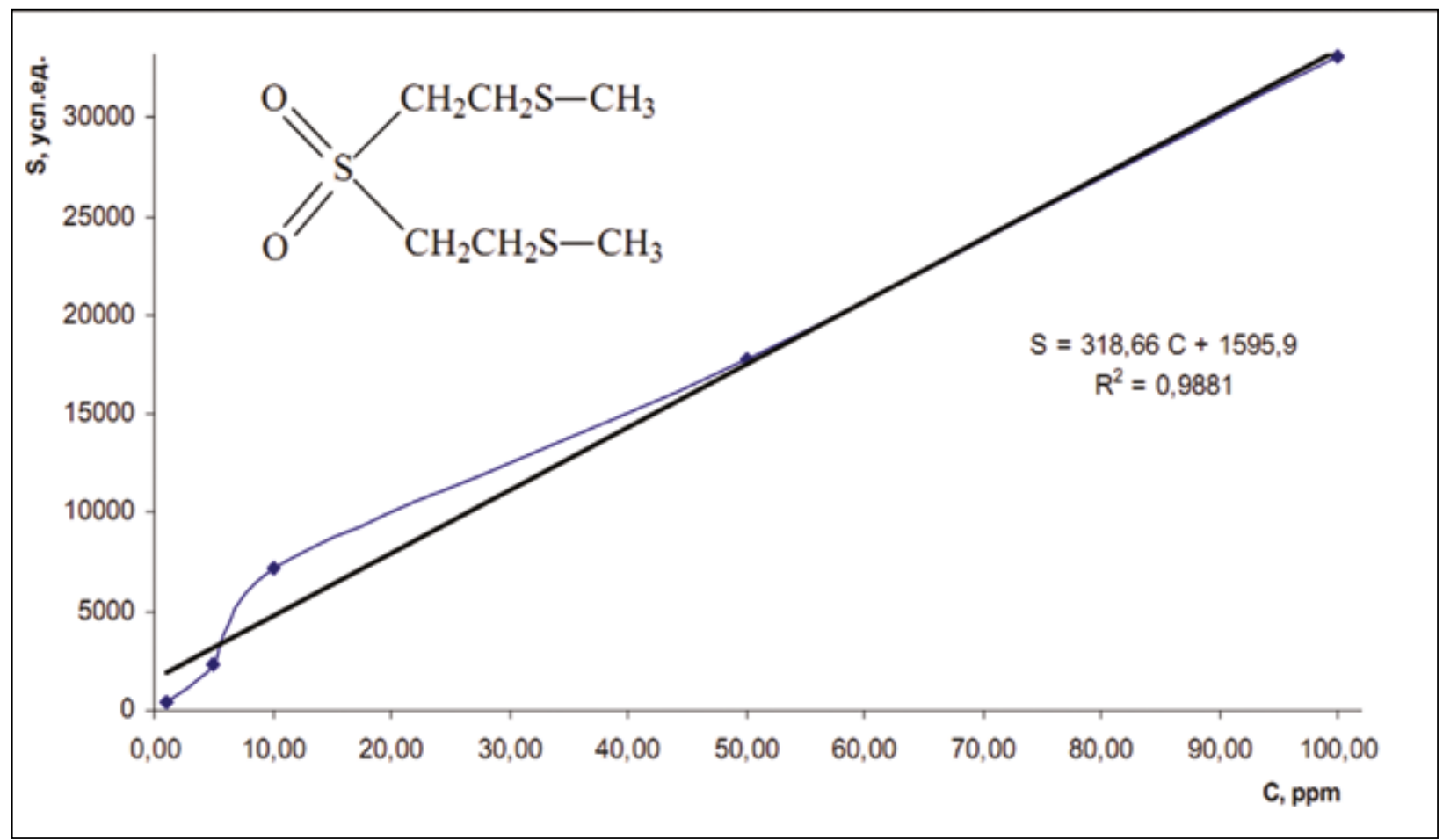

Рисунок 10 - График зависимости показателя площади хроматографического пика TIC-MRM (по двум массэнергетическим переходам) от концентрации SBMTE (3) в моче (сналоженной линией тренда)

фического пика TIC-MRM (по двум массэнергетическим переходам) от концентрации исследуемых биомаркеров (1-3) в моче и в плазме крови, рассчитанные математические модели имеют линейный характер, среднеквадратичные отклонения $\left(\mathrm{R}^{2}>0,99\right)$ коррелируют по обеим координатам точек и в целом в рассчитанной функции. Это обстоятельство свидетельствует о валидности построенных функциональных зависимостей и 


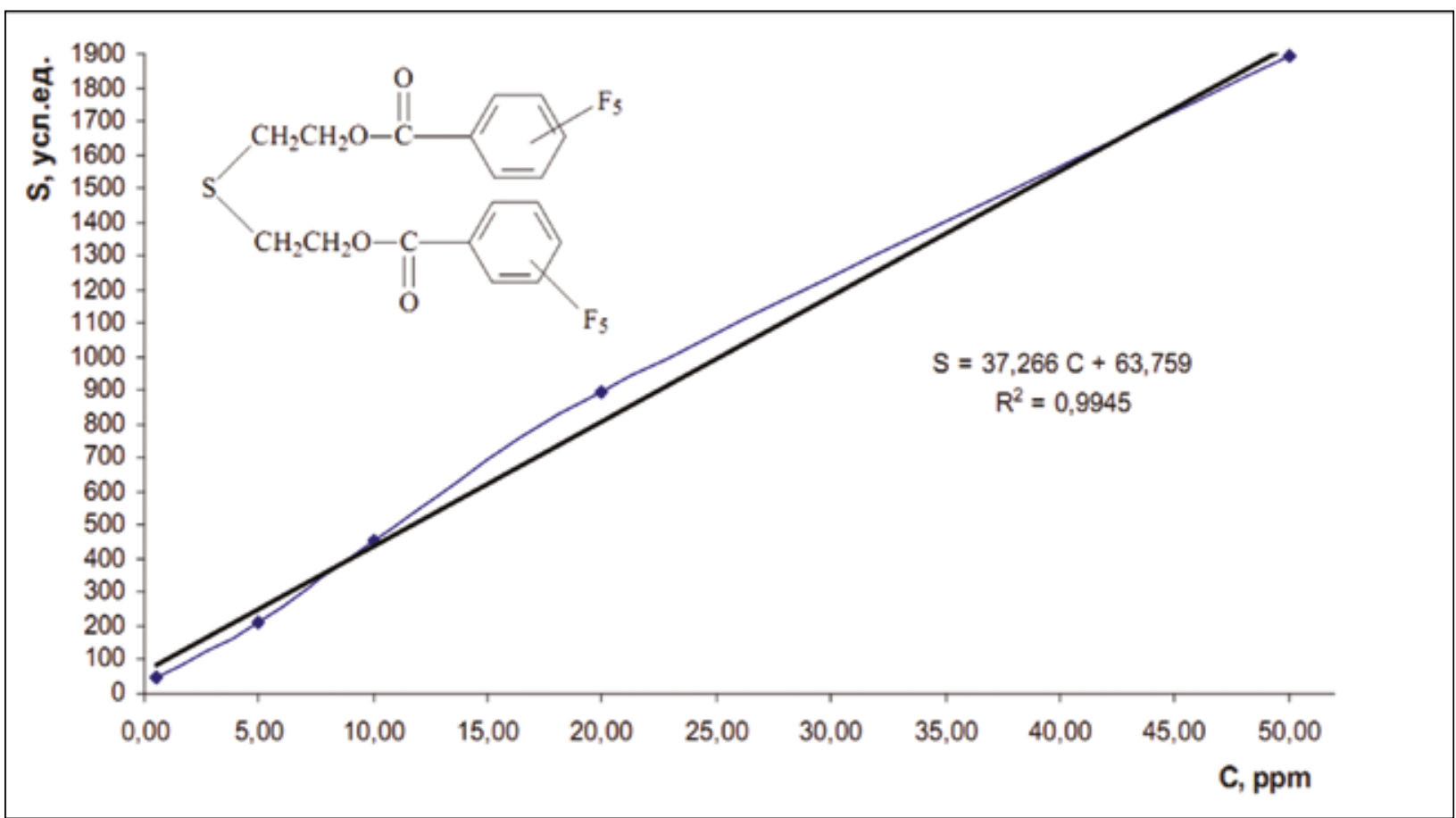

Рисунок 11 - График зависимости показателя площади хроматографического пика TIC-MRM (по двум массэнергетическим переходам) от кониентрации TDGPFB (1) в плазме крови (сналоженной линией тренда)

может быть использовано в дальнейшем для определению биомаркеров серного иприта в разработки соответствующих методик по моче и в крови человека.

Таблица 3 - Отношение показателей сигнал/шум (SNR) от концентрации исследуемых биомаркеров серного иприта (1-3) в различных биосредах

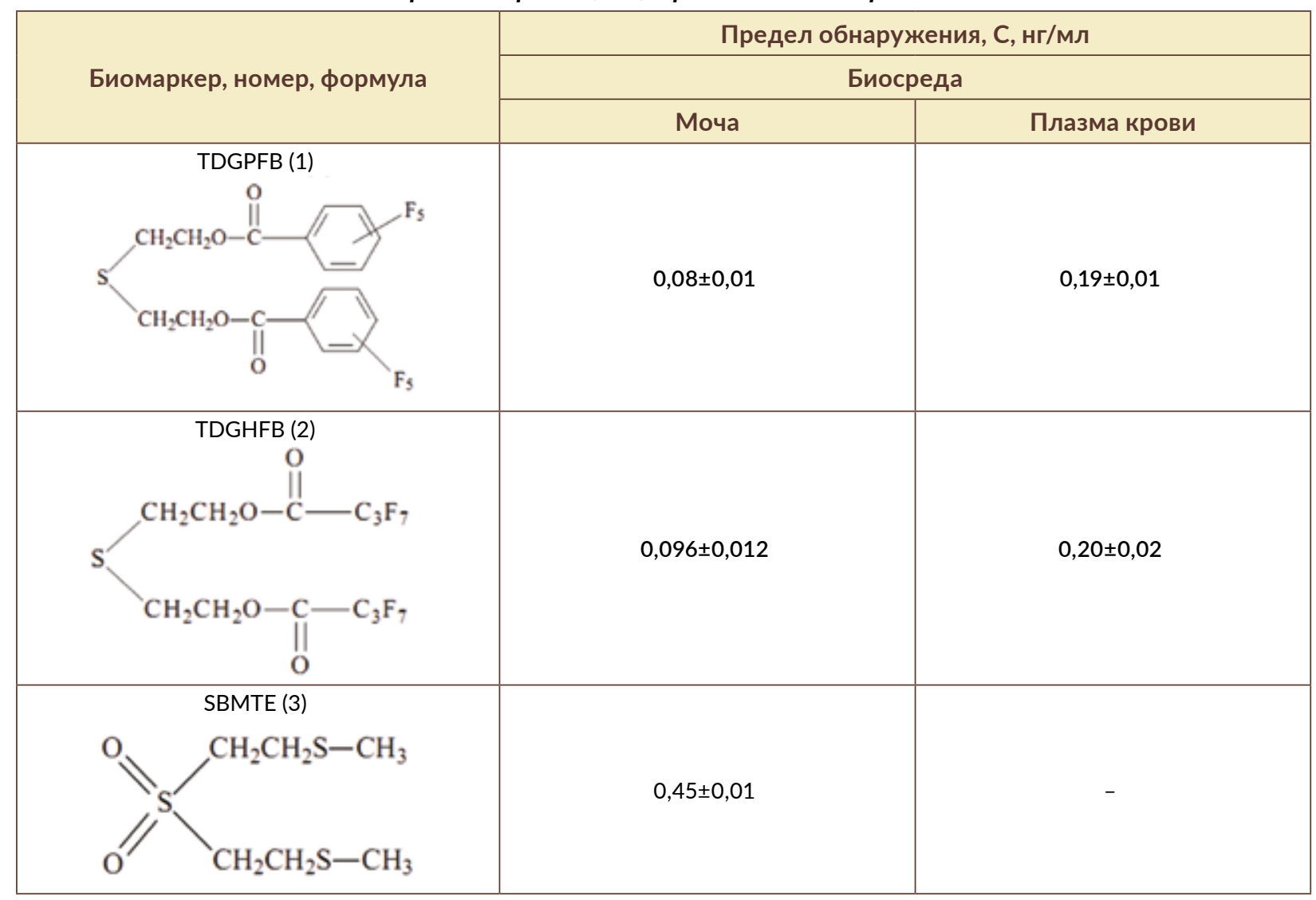


Исходя из полученных значений соотношений сигнал/шум и определенных при этом концентраций обнаруженных биомаркеров, приведенных в таблице 2, были рассчитаны пределы обнаружения данных веществ в моче и в плазме крови в принятых условиях эксперимента (таблица 3).

Необходимо отметить, что полученные пределы обнаружения (в одинаковых условиях хроматографирования и масс-селективного детектирования) биомаркеров серного иприта TDGPFB (1), TDGHFB (2) и SBMTE (3) в стандартных растворах во всех случаях оказались ниже полученных экспериментальных данных для мочи и плазмы крови на 10 и $15 \%$ соответственно. При этом при математической обработке данных полученные среднеквадратичные отклонения в линейной зависимости также коррелируют по отдельным координатам точек и в целом в рассчитанной функции $[7,8]$.

Полученные выше результаты были использованы при разработке способов определения маркеров серного иприта в биологических пробах с использованием газового хроматографа «Agilent 7890A» и трехквадрупольного масс-селективного детектора «Agilent 7000B GC/MS Triple Quad» в режимах химической ионизации.

Информация о конфликте интересов

Авторы заявляют, что исследования проводились при отсутствии любых коммерческих или финансовых отношений, которые могли бы быть истолкованы как потенциальный конфликт интересов.

\section{Сведения о рецензировании}

Статья прошла двойное рецензирование двумя рецензентами, специалистами в данной области. Рецензии находятся в редакции журнала.

\section{Список источников}

1. Convention on the prohibition of the development, production, stockpiling and use of chemical weapons and on their destruction (English version). Printed and distributed by the Technical Secretariat of the Organization for the Prohibition of Chemical Weapons, 2005.

2. Barr J.R., Pierce C.L., Smith J.R. et al. Analysis of Urinary Metabolites of Sulfur Mustard in Two individuals after Accidental Exposure // J. Anal. Toxicol. 2008. V. 32, № 1. P. 10-16.

3. Lin Y., Dong Y., Chen J. et al. Gas chromatographic-tandem mass spectrometric analysis of $\beta$-lyase metabolites of sulfur mustard adducts with glutathione in urine andits use in a rabbit cutaneous exposure model // J. Chromatogr. B Analyt. Technol. Biomed. Life Sci. 2014. V. 945-946. P. 233-239.

4. Young C.L., Ash D., Driskell W.J. et al. A Rapid, Sensitive Method for the Quantitation of Specific Metabolites of Sulfur Mustard in Human Urine Using Isotope-Dilution
Gas Chromatography-Tandem Mass Spectrometry // J. Anal. Toxicol. 2004. V. 28. № 5. P. 339-345.

5. Xu H., Nie Z., Zhang Y. et al. Four Sulfur Mustard Exposure Cases: Overall Analysis of Four Types of Biomarkers in Clinical Samples Provides Positive Implication for Early Diagnosis and Treatment Monitoring // Toxicol. Rep. 2014. V. 1. P. 533-543.

6. Nie Z., Liu Q., Xie J. Improvements in Monitoring the N-terminal Valine Adduct in Human Globin after Exposure to Sulfur Mustard and Synthesis of Reference Chemicals. Talanta. 2011. V. 85 2. P. 1154-1159.

7. Black R.M., Brewster K., Clarke R.J. et al. Biological Fate of Sulphur Mustard, 1,1'-Thiobis(2chloroethane): Isolation and identification of Urinary Metabolites Following Intraperitoneal Administration to Rat // Xenobiotica. 1992. V. 22, № 4. P. 405-418.

8. Black R.M. An Overview of Biological Markers of Exposure to Chemical Warfare Agents // J. Anal. Toxicol. 2008. V. 32, № 1. P. 2-9.

Об авторах

Федеральное государственное бюджетное учреждение «27 Научный центр» Министерства обороны Российской Федерации, 105005, г. Москва, Бригадирский переулок, д. 13.

Корнеев Дмитрий Олегович. Старший научный сотрудник отдела, канд. хим. наук, доц.

Петракова Лидия Васильевна. Научный сотрудник отдела.

Понсов Михаил Александрович. Старший научный сотрудник отдела, канд. хим. наук, доц.

Родионов Александр Анатольевич. Старший научный сотрудник отдела, канд. техн. наук, проф. АВН.

Контактная инбормация для всех авторов: 27nc_1@mil.ru Контактное лиць: Корнеев Дмитрий Олегович; 27nc_1@mil.ru 


\title{
ELABORATION OF A METHOD FOR THE DETERMINATION OF LOW-MOLECULAR-WEIGHT MUSTARD GAS BIOMARKERS IN BIOLOGICAL SAMPLES
}

\author{
D.O. Korneev, L.V. Petrakova, M.A. Ponsov, A.A. Rodionov
}

\begin{abstract}
Federal State Budgetary Establishment "27 Scientific Centre» of the Ministry of Defence of the Russian Federation, Brigadirskii Lane 13, Moscow 105005, Russian Federation
\end{abstract}

\begin{abstract}
The relevance of the development and the improvement of methods for the determination of metabolites (biomarkers) of toxic substances in biological fluids (blood, urine, etc.) is associated with the need to establish facts of humans and animals exposure to toxic chemicals. The need for such analysis arises within the framework of monitoring of the compliance with the provisions of the Chemical Weapons Convention (CWC), when conducting investigations into the alleged use of chemical agents, as well as within the framework of the official proficiency tests carried out by the Organization for the Prohibition of Chemical Weapons (OPCW). Nowadays there exists the problem of the determination of low-molecular-weight mustard gas biomarkers in biological samples with the use of gas chromatography methods with mass-selective detection. The lowmolecular-weight biomarkers of sulfur mustard (SM) are thiodiglycol, oxides and sulfoxides. The identification and quantitative assessment of SM markers in blood and urine is carried out according to the methods, based on the displacement of thiodiglycol and its derivatives from protein conjugates with titanium trichloride, solidphase extraction, concentration in ethyl acetate solution, derivatization with pentafluorobenzoyl chloride, heptafluorobutyrylimidazole, heptafluorobutyric acid anhydride or chloride, subsequent stripping of the derivative into the appropriate solvent and GH-MS analysis (chemical ionization technique with methane as a reagent gas with the registration of negative ions). After the sample preparation, the limits of detection of the minimum values of ultra-low concentrations of the analyzed biomarkers of SM in urine and blood plasma were determined. After the chromatographic analysis, the corresponding graphs of indicators have been constructed, based on the concentrations of biomarkers in urine and blood plasma. Later on they have been used for the elaboration of the methods for the determination of SM biomarkers in human urine and blood.
\end{abstract}

Keywords: biomarkers; beta-lyase metabolites; Convention; nanodashes; poisonous substances; plasma sample preparation; sample preparation; toxic chemicals; chemical weapons; chromatographic separation; chromatographic peak; environmental study.

For citation: Korneev D.O., Petrakova L.V., Ponsov M.A., Rodionov A.A. Elaboration of a method for the determination of low-molecular-weight mustard gas biomarkers in biological samples // Journal of NBC Protection Corps. 2018. V. 2. № 3. P. 40-54.

Conflict of interest statement

The authors declare that the research was conducted in the absence of any commercial or financial relationship that could be construed as a potential conflict of interest.

Peer review information

The article has been peer reviewed by two experts in the respective field. Peer reviews are available from the Editorial Board.

References

References List see P. 53.

Authors

Federal State Budgetary Establishment «27 Scientific Centre» of the Ministry of Defence of the Russian Federation. Brigadirskii Lane 13, Moscow 105005, Russian Federation.

Korneev Dmitry Olegovich. Senior Researcher of the Department. Candidate of Chemical Sciences, Associate Professor.

Petrakova Lidia Vasilyevna. Researcher of the Department.

Ponsov Mikhail Aleksandrovich. Senior Researcher of the Department. Candidate of Chemical Sciences, Associate Professor.

Rodionov Aleksandr Anatolyevich. Senior Researcher of the Department. Candidate of Technical Sciences, Professor of the Academy of Military Sciences.

Contact information for all authors: 27nc_1@mil.ru Contact person: Korneev Dmitry Olegovich; 27nc_1@mil.ru 


\title{
ДЕЯТЕЛЬНОСТЬ МОБИЛЬНОЙ ДИАГНОСТИЧЕСКОЙ ГРУППЫ 27 НЦ МО РФ
}

\author{
М.П. Шабельников, В.Г. Михайлов, А.В. Терновой, \\ А.В. Комратов, Е.В. Макейкин, С.В. Кужелко
}

\begin{abstract}
Федеральное государственное бюджетное учреждение "27 Научный центр» Министерства обороны Российской Федерачии, 105005, Российская Федерация, г. Москва, Бригадирский переулок, д. 13
\end{abstract}

\begin{abstract}
Поступила 11.05.2018 г. Принята к публикации 10.09.2018 г.
В настоящей статье представлены данные о деятельности мобильной диагностической группы федерального государственного бюджетного учреждения «27 Научный центр» Министерства обороны Российской Федерации. Приведены сведения об их составе и выполняемых задачах. В частности, описаны действия личного состава при проведении радиационной, химической и биологической разведки территории островов Курильской гряды и территории полуострова Крым; при обследовании объектов, предусматривающих массовое скопление людей, в том числе присутствие первых лиц государства и руководящего состава Министерства обороны Российской Федерации, на наличие отравляющих веществ и источников ионизирующих излучений. Получены сведения, необходимые для прогнозирования обстановки в районе проведения охранных мероприятий. Показано, что опыт, накопленный специалистами мобильной диагностической группы с момента ее создания, позволяет им успешно выполнять задачи по предназначению в условиях нарастания, а также постоянного изменения современных угроз радиационного, химического, биологического характера.
\end{abstract}

Ключевые слова: отравляющее вещество; оценка и прогнозирование обстановки; радиационная, химическая, биологическая разведка; радиационный контроль; химический контроль.

Библиографическое описание: Шабельников М.П., Михайлов В.Г., Терновой А.В., Комратов А.В., Макейкин Е.В., Кужелко С.В. Деятельность мобильной диагностической группь 27 НЦ МО РФ // Вестник войск РХБ защзиты. 2018. Т. 2. № 3. С. 55-63.

Научно-технический прогресс не только способствует повышению производительности и улучшению условий труда, росту материального благосостояния и интеллектуального потенциала общества, но и приводит к появлению новых угроз, к возрастанию риска возникновения аварий и катастроф, сопровождающихся чрезвычайными ситуациями $[1,2]$. Для предотвращения возникновения таких ситуаций и оперативного реагирования на чрезвычайные ситуации, связанные с попаданием опасных биологических агентов и химических веществ в окружающую среду, между заинтересованными федеральными органами исполнительной власти разграничены полномочия в указанной области ${ }^{1}$.

В федеральном государственном бюджетном учреждении «27 Научный центр» Мини-

\footnotetext{
${ }^{1}$ Постановление Правительства РФ от 16 мая 2005 г. № 303 «О разграничении полномочий федеральных органов исполнительной власти в области обеспечения биологической и химической безопасности Российской Федерации». URL: http://base.garant.ru/12140131/ (дата обращения: 02.04. 2018).
} 